\title{
ВЛИЯНИЕ СУЛЬФАТРЕДУЦИРУЮЩИХ БАКТЕРИЙ НА ВОЗНИКНОВЕНИЕ ПАРОДОНТИТА
}

\section{THE EFFECT OF SULFATE-REDUCING BACTERIA ON THE OCCURRENCE OF PERIODONTITIS}

T. Simonyan

Summary. Sulfate-reducing bacteria (SRB) may be etiologically involved in destructive periodontal diseases. The aim of this study is to summarize the species diversity of SRB in the oral cavity, to characterize periodontitis and describe the connection between SRB and the products of their metabolism with the etiology of this disease. Periodontal sulfate-reducing bacteria are associated with several clinical categories of periodontitis and with periodontal sites of increased pocket depth.

Keywords: sulfate-reducing bacteria, influence, etiology, periodontitis.

\author{
Симонян Татьяна Владимировна \\ К.м.н., преподаватель, Пятигорский медико- \\ фармацевтический институт - филиал \\ Волгоградского государственного медицинского \\ университета \\ shpitzbaum@mail.ru
}

Аннотация. Сульфатредуцирующие бактерии (SRB) могут быть этиологически вовлечены в деструктивные заболевания пародонта. Целью данного исследования является обобщение видового разнообразия SRB в полости рта, характеристика пародонтита и описание связи между SRB и продуктами их метаболизма с этиологией этого заболевания. Сульфатредуцирующие бактерии пародонта связаны с несколькими клиническими категориями пародонтита и с участками пародонта с увеличенной глубиной карманов.

Ключевые слова: сульфатредуцирующие бактерии, влияние, этиология, пародонтит.

получения энергии и вытесняют образующийся сульфид как отходы; это известно как диссимиляционное восстановление сульфата. Они используют сульфат в качестве конечного акцептора электронов в своей цепи переноса электронов. Большинство из них - анаэробы [3].

Сульфат широко встречается в морской воде, отложениях или воде, богатой разлагающимся органическим материалом. Сульфатредуцирующие бактерии распространены в анаэробных средах, где они способствуют разложению органических материалов. В этих анаэробных средах ферментирующие бактерии извлекают энергию из крупных органических молекул; образующиеся более мелкие соединения, такие как органические кислоты и спирты, дополнительно окисляются ацетогенами, метаногенами и конкурирующими сульфатредуцирующими бактериями [4].

SRB встречаются во рту примерно у 10\% здоровых людей. У пациентов с пародонтитом частота их возникновения значительно выше, достигая 86\%, и связана с увеличением глубины пародонтальных карманов и их кровотечением [5]. Эти факты свидетельствуют о том, что SRB являются частью нормальной микробиоты полости рта, но предпочитают пародонтальные карманы, которые идеально подходят для роста этих бактерий, учитывая их анаэробные условия роста.

Бактерии рода Desulfomicrobium представляют coбой неспорообразующие грамотрицательные палоч- 
ковые клетки, обычно подвижные с одним или двумя полярными жгутиками. Род Desulfomicrobium метаболически идентичен роду Desulfovibrio, но характеризуется стержнеобразной морфологией и содержанием бисульфатредуктазы с десульфорубидином вместо деульфовиридина. Основным очагом их возникновения является грязь и отложения, но новый вид Desulfomicrobium orale был изолирован от пациентов с пародонтитом из пародонтальных карманов [6].

В настоящее время достаточно распространенной является проблема пародонтита - это хроническое многофакторное воспалительное заболевание, связанное с дисбиотической биопленкой зубного налета и характеризующееся постепенным разрушением суспензии зубов. Пародонтит - хроническое воспалительное заболевание, поражающее ткани, поддерживающие зубы, так называемый пародонт. Это ткань, окружающая зубы и фиксирующая их на своем месте; он также служит первым барьером против проникновения примесей, бактерий и других вредных элементов. Пародонт состоит из десны (ткани десны), цемента (внешний слой корней зубов), альвеолярной кости (костные впадины, в которые крепятся зубы) и периодонтальных связок. Формируются пародонтальные карманы; постоянное воспаление и инфекция не позволяют им самопроизвольно заживать, как в случае с поверхностью тела [7].

Пародонтит - хроническое воспалительное заболевание тканей пародонта с неясной и малоизученной этиологией. Однако его развитие связано с изменением бактериального состава биопленки зубного налета. Клиническая потеря прикрепления является преобладающим клиническим проявлением и определяющим фактором заболевания пародонта, а его потеря является признаком деструктивного (физиологически необратимого) заболевания пародонта. Пародонтит - заболевание с множеством клинических проявлений, и его клиническое описание постоянно уточняется и обновляется. Основные признаки включают потерю поддержки тканей пародонта, что приводит к клинически значимой потере фиксации зуба в области шейки и корня зуба и рентгенологически оцениваемой потере альвеолярной кости, образованию и наличию настоящих пародонтальных карманов между деснами и зубом, а также кровоточивости десен [8].

В связи с наблюдаемым увеличением заболеваемости SRB в полости рта у пациентов с пародонтитом рассматривается возможность токсического воздействия $\mathrm{H} 2 \mathrm{~S}$ на эпителиальные клетки ротовой полости, что может привести к возникновению и дальнейшему развитию заболевания. $\mathrm{H} 2 \mathrm{~S}$ действует как ингибитор клеточной цитохромоксидазы, а также может иметь вторичный эф- фект, разрушая дисульфидные связи в белках, что влияет на гранулоциты и их функцию в иммунной системе [9].

Пародонтит чаще всего возникает у людей с избыточным количеством зубного налета, что подтверждает теорию о том, что микроорганизмы и их метаболиты играют роль в развитии этого заболевания. Микробиом полости рта был разделен на несколько групп в соответствии с таксономической конгениальностью, при этом некоторые комплексы в большей степени связаны с заболеваниями пародонта, что привело к выводу, что некоторые виды микроорганизмов имеют более высокий патогенетический потенциал, чем другие.

Сульфатредуцирующие бактерии (SRB) могут быть этиологически вовлечены в деструктивные заболевания пародонта. Эти строго анаэробные бактерии используют продукты ферментации для сохранения энергии за счет восстановления сульфата до сульфида. Этот токсичный продукт может накапливаться в пародонтальных карманах в концентрациях, вызывающих разрушение клеток. SRB зависят от активно разлагающейся микробиоты, чтобы производить восстановленную среду, продукты ферментации и сульфаты. Частота обнаружения этих бактерий значительно выше при пародонтите по сравнению со здоровыми участками полости рта [10].

Протеолитическая активность во рту - важный фактор в развитии неприятного запаха изо рта. Летучие соединения серы (VSC) - это газы, которые в первую очередь ответственны за неприятный запах изо рта - состояние, при котором во рту присутствуют нежелательные неприятные запахи. VSC образуются в результате метаболизма белков бактерий. Эти метаболиты включают многие соединения, такие как скатол, H2S, метантиол и диметилсульфид. Исследования показали, что эти соединения токсичны даже при низких концентрациях. Другими словами, VSC также могут вносить вклад В этиологию как гингивита, так и пародонтита [11].

SRB - это гетерогенная группа встречающихся в природе видов, которые разделяют способность диссимиляционного восстановления сульфата до H2S. H2S - высокотоксичный агент (который вызывает повреждение клеток подобно цианиду) со смертельным исходом из-за инактивации цитохромоксидазы. Цитохромоксидаза это трансмембранный белок митохондрий, последний фермент в цепи респираторного транспорта электронов. О2 не может связываться с ним после его блокировки, что приводит к невозможности синтеза АТФ и, следовательно, производства энергии. Сульфид был обнаружен в более глубоких пародонтальных карманах в концентрациях, достаточно высоких, чтобы инактивировать клеточную цитохромоксидазу. Накопление $\mathrm{H} 2 \mathrm{~S}$ также может иметь вторичный токсический эффект - 
он способен расщеплять дисульфидные связи в белках, вступать с ними в реакцию и связывать ионы различных металлов. Это может повлиять на способность гранулоцитов опсонизировать микроорганизмы, что приведет к подавлению иммунного ответа в пародонтальном кармане. H2S также ингибирует миелопероксидазу и каталазу [12].

Пародонтит - это в определенной степени излечимое заболевание, лечение которого сочетает консервативную терапию с хирургическим лечением, надлежащее воздействие которого требует длительного соблюдения гигиены полости рта. Конечным продуктом диссимиляционного восстановления сульфата является $\mathrm{H} 2 \mathrm{~S}$, который оказывает токсическое действие на эпителиальные клетки полости рта. Он действует как ингибитор клеточной цитохромоксидазы, а также может иметь вторичный эффект, разрушая дисульфидные связи белков, влияя на гранулоциты и их функции в иммунной системе. Метаанализ трех исследований, посвященных присутствию SRB-положительных людей в полости рта, показал, что процент SRB-положительных людей выше у людей с пародонтитом [13].

В исследовании Petra Langendijk-Genevaux и соавт. наличие SRB определялось в зависимости от клинических особенностей пациентов и локальных клинических параметров пародонтита, таких как глубина кармана, кровотечение и уровень прикрепления. В исследование были включены пациенты с клиническими характеристиками тяжелого пародонтита ( $\mathrm{n}=87), 78$ пациентов не получали лечения, а 9 пациентов получали поддерживающую терапию после лечения. Образцы были взяты ( $\mathrm{n}=261$ ) из самых глубоких пародонтальных карманов, и наличие SRB было определено путем обогащения культуры в бескислородной камере.

Результаты исследования были следующие: у 64\% пациентов SRB присутствовали как минимум в 1 кармане. Они возникали среди пациентов от 23 до 57 лет и чаще всего преобладали среди пациентов старше 30 лет. Наблюдалась тенденция к увеличению встречаемости SRB у пациентов с более чем 50\% участков кровотечения или с несколькими угловатыми костными дефектами или развилками. SRB присутствовали в 44\% пародонтальных карманов. Они, как правило, преобладали в карманах с кровотечением при зондировании, развилках, угловатых костных дефектах или эндодонтическом осложнении. Наличие SRB положительно коррелировало с увеличением глубины кармана ( $<<0,05)$.

Было обнаружено, что SRB связаны с различными клиническими категориями пародонтита, включая пародонтит с ранним началом, быстро прогрессирующий пародонтит, пародонтит взрослых и рефрактерный пародонтит. Хотя SRB преобладал среди пациентов со взрослой формой пародонтита, то есть с частотой $72 \%$, значимой корреляции с возрастом пациента не было. Среди пролеченных пациентов на поддерживающей терапии распространенность SRB была значительно снижена по сравнению с нелеченными пациентами $(p<0,02)$. Возникновение SRB в пародонтальных карманах показало отношение шансов 11,2 по сравнению со здоровыми участками полости рта [14].

Таким образом, нами установлено, что одно из самых распространенных воспалительных заболеваний полости рта - пародонтит. Увеличение SRB в карманах при несъёмном протезировании зависит от определенной активности микробов, разрушающих ткани. Кроме того, бактерии продуцируют фактор вирулентности H2S, который может усиливать процесс разрушения тканей пародонта, поэтому присутствие SRB может служить индикатором деградации тканей в пародонтальном кармане.

Также нарушение микробиоценоза в полости рта может привести к воспалению слизистой оболочки протезного ложа и протезным стоматитам. Последствиями инфекционных воспалительных процессов, связанных с протезированием, являются прогрессирующая деструкция пародонта и костной ткани альвеолярной кости, возникновение дефектов зубных рядов, нарушение жевательной функции пациента

Есть еще много безответных вопросов о точном механизме возникновения пародонтита и о том, действительно ли он связан с сульфатредуцирующими и / или другими бактериями. Поэтому необходимо продолжить исследования микробных популяций ротовой полости и их влияния на ткани, в которых они обитают.

\section{ЛИТЕРАТУРА}

1. Alexander M. Microbial ecology / M. Alexander. - New York, 2008. - P. 3-93.

2. Guan F, Zhai X, Duan J, Zhang M, Hou B (2016) Influence of Sulfate-Reducing Bacteria on the Corrosion Behavior of High Strength Steel EQ70 under Cathodic Polarization. PLOS ONE11(9): e0162315.

3. Hamilton WA (1985) Sulphate-reducing bacteria and anaerobic corrosion Ann. Rev. Microbiol. 39, 159-217

4. Kotrsová, V.; Kushkevych, I. Possible methods for evaluation of hydrogen sulfide toxicity against lactic acid bacteria. Biointerface Res. Appl. Chem. 2019, 9, 40664069. 
5. Kushkevych, I. V. Kinetic Properties of Pyruvate Ferredoxin Oxidoreductase of Intestinal Sulfate-Reducing Bacteria Desulfovibrio piger Vib-7 and Desulfomicrobium sp. Rod-9. Pol. J. Microbiol. 2015, 64, 107-114

6. Hao, 0.J.; Chen, J.M.; Huang, L.; Buglass, R. L. Sulfate-reducing bacteria. Crit. Rev. Environ. Sci. Technol. 1996, 26, 155-187.

7. Darout, I. A. Oral Bacterial Interactions in Periodontal Health and Disease. J. Dent. Oral Hyg. 2014, 6, 51-57.

8. Hasturk, H.; Kantarci, A.; Van Dyke, T. E. Oral inflammatory diseases and systemic inflammation: Role of the macrophage. Front. Immunol. $2012,3,118$.

9. Loesche, W.J.; Grossman, N. S. Periodontal Disease as a Specific, Albeit Chronic, Infection: Diagnosis and Treatment. Clin. Microbiol. Rev. $2001,14,727-752$.

10. Marsh, P.D.; Devine, D. A. How Is the Development of Dental Bio-films Influenced by the Host? Host Influence on Biofilm Development. J. Clin. Periodontol. 2011, 38, $28-35$.

11. Kushkevych I, Coufalová M, Vítězová M, Rittmann SK-MR. Sulfate-Reducing Bacteria of the Oral Cavity and Their Relation with Periodontitis — Recent Advances. Journal of Clinical Medicine. 2020; 9(8):2347.

12. Darveau, R. P. Periodontitis: A Polymicrobial Disruption of Host Homeostasis. Nat. Rev. Microbiol. 2010, 8, 481-490.

13. Langendijk, P.S.; Hanssen, J.T.J.; Van der Hoeven, J. S. Sulfate-Reducing Bacteria in Association with Human Periodontitis. J. Clin. Periodontol. 2000, $27,943-950$.

14. Petra Langendijk-Genevaux, J.T.J. Hanssen, J.S. van der Hoeven, Sulfate-reducing bacteria in association with human periodontitis. Journal Of Clinical Periodontology 27(12):943-50. DOI: 10.1034/j.1600-051x.2000.027012943

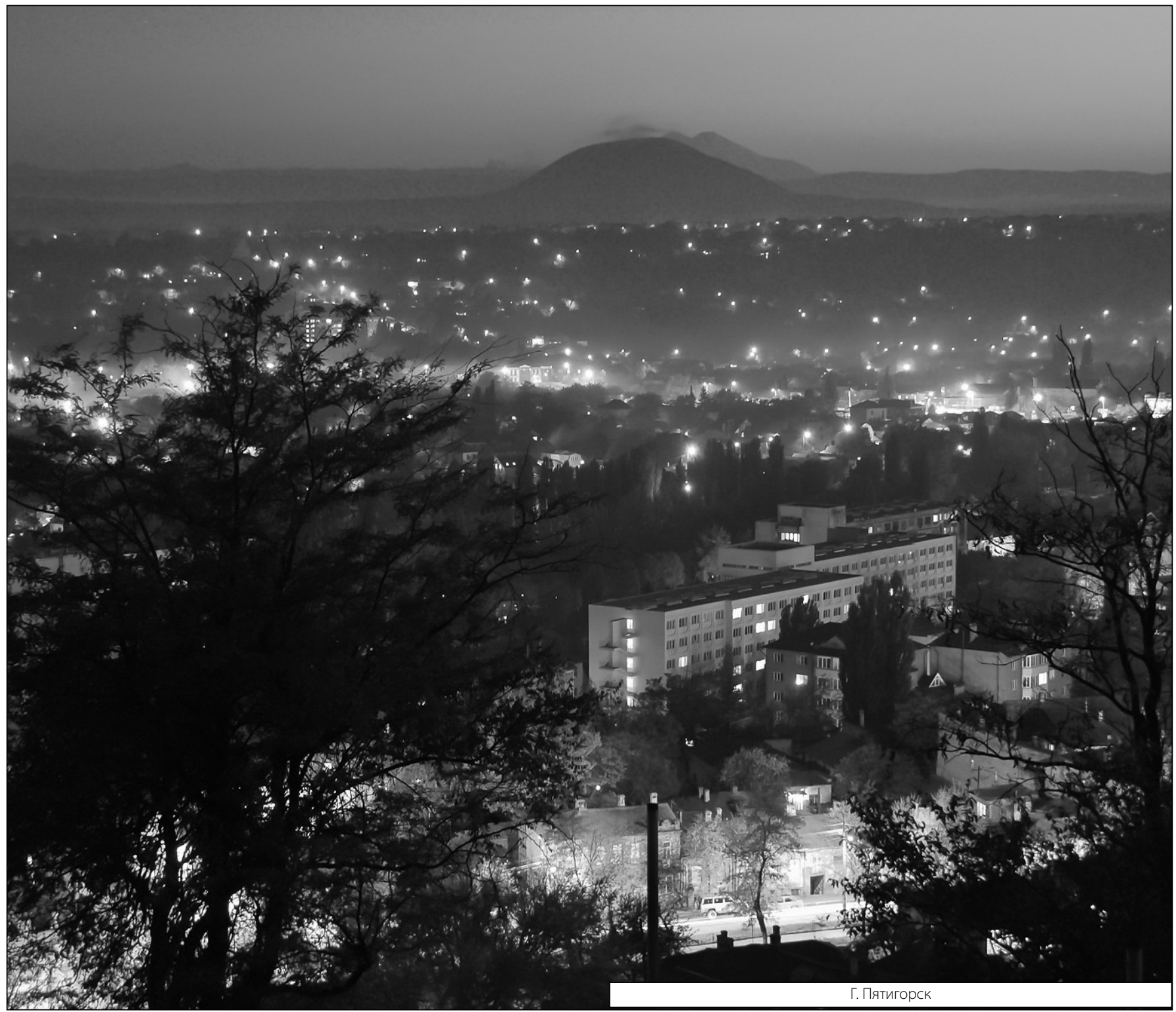

